\title{
Pengaruh Model Pembelajaran Problem Based Learning Berbantuan Media Couple Card terhadap Higher Order Thingking Skilss Siswa pada IPA Biologi di SMP Negeri 10 Kota Kupang
}

\section{The Effect of Learning Method Problem Based Learning Assisted by Couple Card Media Toward Higher Order Thingking Skill Students of Biology Science in SMP Negeri 10 Kota Kupang}

\author{
Fransina Thresiana Nomleni*, Nubatonis, P, A \\ Pendidikan Biologi Fakultas Keguruan dan Ilmu Pendidikan Universitas Kristen Artha Wacana \\ Jl. Adi Sucipto No 147, Oesapa, kelapa lima, Kota Kupang, Indonesia \\ *Corresponding authors: nomlenifince@gmail.com
}

\begin{abstract}
This study aims to determine the effect of Problem Based Learning (PBL) aided by Couple Card media on HOTS students in Biology Science. The method used in this study is an experimental method with a Posstest-Only Control Design. The population of all VIII grade students in SMP N 10 Kupang was 314 students with a sample of class VIIIA dan class VIIID totaling 62 students. The sampling technique used is Simple Random Sampling. Data collection techniques using observation and description test based on the rubric guideline scores. Data analysis techniques used descriptive analysis and parametric statistic consisting of prerequisite test (normality and homogeneity tests) and hypothesis tests (T-tests). Data is processed with the help of SPSS.19 for windows. The prerequisite test analysis results obtained that the HOTS value data of students is normally distributed and homogeneous. Percentage of the average value of HOTS students in the experimental class viewed from the cognitive aspects of analysing $72.65 \%$, evaluating $73.04 \%$, and creating $68.75 \%$. the cognitive aspects of the control class analysing $28.75 \%$, evaluating $30.83 \%$, and creating $31.66 \%$. While the value of the hypothesis test results obtained $t$ value of 12.241 with a significance of 0,000 ( 2 -tailed $<0.05$ ) shows that there is significant influence on the HOTS of students who are taught using PBL assisted by Couple Card Media. This can be seen from the increasing interest of students in folowing the lessons, students appear to be more active, competitive, critical and creative in solving problems encountered, and students are able to explore their thingking skills to solve problems in the stages of analysing, evaluating, and creating. this is because the Problem Based Learning model assisted by Couple Card media has considerable potential that is able to develop students high level thingking skills. so it can be concluded that $\mathrm{H} 1$ is accepted and $\mathrm{H} 0$ is rejected, it means that PBL learning model assisted by Couple Card media influences students' HOTS on natural Sciences.
\end{abstract}

Keywords: Problem Based Learning Model, Couple Card, HOTS

\section{PENDAHULUAN}

Pembelajaran adalah serangkaian aktivitas yang dilakukan siswa guna mencapai hasil belajar tertentu di bawah bimbingan, arahan, dan motivasi guru. Berdasarkan pengertian ini, pembelajaran bukanlah proses yang didominasi oleh guru melainkan siswa itu sendiri (Abidin, 2014:6). Dalam pembelajarannya guru membutuhkan adanya sebuah perencanaan yang baik. Perencanaan dalam proses pembelajaran di kelas bertujuan untuk tercapainya kompetensi siswa. Hal tersebut menjelaskan bahwa perencanaan merupakan langkah-langkah untuk mempermudah dalam mencapai tujuan. Tahap perencanaan dalam proses pembelajaran akan menentukan penggunaan model pembelajaran yang akan diterapkan.

Model pembelajaran dapat didefinisikan sebagai kerangka konseptual yang menggambarkan prosedur sistematis untuk mencapai tujuan belajar. Model pembelajaran dalam pendidikan memiliki banyak variasi dan jenis, diantaranya adalah model pembelajaran berbasis pada masalah (Problem Based Learning). Model Problem
Based Learning (PBL) merupakan model pembelajaran yang ditawarkan sebagai salah satu model yang cocok untuk dipakai pada kurikulum 2013. Model pembelajaran Problem Based Learning merupakan suatu pembelajaran yang menghadapkan siswa pada permasalahanpermasalahan dunia nyata yang biasa mereka jumpai di sekeliling mereka sebagai pijakan dalam belajar atau siswa dapat belajar dari permasalahan-permasalahan tersebut. Sasaran dari kegiatan pembelajaran berbasis masalah adalah keaktifan, kreativitas serta kemampuan siswa dalam memecahkan masalah yang dihadapi.

Menurut Rusman (dalam Fathurrohman, 2017:112) mengemukakan bahwa Problem Based Learning adalah pembelajaran yang menggunakan masalah nyata (auntetik) yang tidak tersrtuktur dan bersifat terbuka sebagai konteks bagi peserta didik untuk mengembangkan keterampilan menyelesaikan masalah dan berpikir kritis serta sekaligus membangun pengetahuan baru. Berbeda dengan pembelajaran konvensional yang hanya menerapkan pemahaman konsep, Problem Based Learning menjadikan masalah nyata sebagai pemicu bagi proses belajar peserta 
didik dalam menggali dan menyelesaikan masalah dengan mencari solusi dan gagasan mereka melalui aktivitas mental dan kognitif terhadap masalah yang diberikan secara kritis.

Model pembelajaran Problem Based Learning akan dibantu dengan media pembelajaran sebagai alat bantu dalam kegiatan belajar yang dapat menumbuhkan sikap ingin tahu, santai namun kritis, dan menciptakan suasana belajar yang menyenangkan. Peranan media sangat penting dalam proses kegiatan belajar. Adapun media yang digunakan dalam penelitian yang dilakukan berupa media kartu berpasangan (Couple card).

Couple Card atau kartu berpasangan menurut Rahmi, et al (2018) adalah sebuah media pembelajaran berbentuk kartu yang berisikan pertanyaan dan kartu lain berisikan jawaban yang saling melengkapi, sehingga lebih mudah untuk melakukan diskusi dan dapat mengaktifkan pikiran siswa dalam berkompetisi dalam memecahkan soal. Salah satu muatan dalam kurikulum 2013 membahas tentang kemampuan berpikir ketingkat lebih tinggi (HOTS). Menurut pendapat Thomas \& Thorne (dalam Riadi, 2016), Kemampuan berpikir tingkat tinggi (HOTS) merupakan kemampuan yang tidak hanya sekedar menghafal saja tetapi mengharuskan siswa melakukan sesuatu atas faktafakta tersebut seperti harus memahami, menganalisis satu sama lain, mengkategorikan, memanipulasi, menciptakan cara-cara baru secara kreatif, dan menerapkannya dalam mencari solusi terhadap persoalan baru. Berdasarkan taksonomi Bloom, keterampilan berpikir tinggi adalah kegiatan berpikir yang melibatkan level kognitif hirarki tinggi. Secara hirarki taksonomi Bloom terdiri dari enam level yaitu pengetahuan (C1) , pemahaman (C2), pengaplikasian (C3) dikategorikan sebagai pemikiran tingkat rendah sedangkan kemampuan analisis (C4), sintesis (C5), dan evaluasi (C6) dikategorikan sebagai kemampuan tingkat tinggi.

Berdasarkan hasil observasi awal di SMP Negeri 10 Kupang dalam proses pembelajaran yang terjadi di kelas VIII SMP Negeri 10 Kupang ditemukan beberapa masalah antara lain keaktifan siswa dalam proses bertanya dan menjawab masih rendah, terlihat dari kurang tertariknya siswa pada pembelajaran menggunakan ceramah dan siswa dominan sibuk sendiri tanpa memperhatikan maupun mendengar penjelasan guru.

Rendahnya kemampuan berpikir tingkat tinggi siswa terlihat dari hasil Ujian Akhir semester mata pelajaran IPA biologi dari 40 soal yang diberikan terdapat 6 soal HOTS dengan masing - masing soal kategori menganalisis, mengevaluasi dan mencipta berjumlah 2 butir soal. Menunjukan kelas VIII ${ }^{\mathrm{A}}$ kemampuan berpikir rata-rata menganalisis (C4) 38\% kategori cukup, kemampuan berpikir mengevaluasi 30\% kategori cukup, kemampuan berpikir mencipta (C6) sebesar $20 \%$ kategori cukup. Dan kelas VIII $^{\mathrm{D}}$ kemampuan berpikir rata-rata menganalisis (C4) 53\% kategori baik, kemampuan mengevaluasi (C5) $40 \%$ kategori cukup sedangkan kemampuan berpikir mencipta (C6) 30\% kategori cukup.

Tujuan penelitian adalah untuk mengetahui ada tidaknya pengaruh model problem based Learning berbantuan media couple card terhadap Higher Order Thinking Skills Siswa dalam pembelajaran IPA Biologi di SMP Negeri 10 kota Kupang.

\section{METODE}

\section{Populasi dan Sampel}

Populasi dari penelitian ini adalah seluruh siswa kelas VIII SMP Negeri 10 Kupang terdiri dari 11 kelas berjumlah 314 siswa. Adapun sampel dalam penelitian ini yakni kelas VIII $^{\mathrm{A}}$ sebagai kelas kontrol dan $\mathrm{VIII}^{\mathrm{D}}$ sebagai kelas eksperimen. Masing-masing kelas berjumlah 30 dan 32 siswa. Pengambilan sampel dilakukan dengan teknik Simple Random Samplin.

\section{Tempat dan Waktu Penelitian}

Penelitian ini dilaksanakan di SMP Negeri 10 Kupang, Jln. Prof. Dr. Herman Yohanes, Kelurahan Lasiana, Kecamatan kelapa lima. Penelitian ini dilaksanakan pada tanggal 21 Oktober sampai 26 Oktober tahun 2019.

\section{Desain Penelitian}

Penelitian ini menggunakan desain Posstest- only Control Design.

\section{Teknik Pengumpulan Data}

Teknik pengumpulan data yang digunakan dalam penelitian ini yaitu observasi, tes dan rubrik penilaian dengan teknik penskoran.

\section{Instrumen Penelitian}

Instrumen yang digunakan dalam penelitian ini yaitu lembar observasi pembelajaran dengan model PBL dengan Couple Card, lembar observasi pembeljaran dengan metode ceramah bervariasi dan soal posstest kemampuan berpikir tingkat tinggi

\section{Teknik Analisis Data}

Data dalam penelitian ini dianalisis menggunakan analisis deskriptif dan statistik parametris. data yang dianalisis secara deskriptif adalah hasil observasi pelaksanaan pembeljaran di kelas dan data hasil tes Postest siswa. Data yang diolah dengan statistik parametris adalah data postest.

Statistik parametris terdiri dua tahap yaitu uji prasyarat dan uji hipotesis. terdapat dua uji prasyarat yang dilakukan, yaitu menggunakan uji homogenitas dan uji normalitas. Uji homogenitas dilakukan untuk mengetahui apakah data yang digunakan bersifat homogen atau tidak. Uji homogenitas dilakukan setelah data lulus ujian normalitas. Perhitungan homogenitas dilakukan dengan menggunakan bantuan komputer program SPSS for Windows versi 19.0, Dasar pengambilan keputusan yaitu dengan melihat angka probabilitas, apabila $\mathrm{p}>0,05$ maka varian dinyatakan homogen. Uji normalitas digunakan untuk memeriksa apakah data yang dianalisis berdistribusi normal atau tidak. Uji normalitas dilakukan dengan uji Kolmogorof- Smirnof dengan bantuan SPSS.19 for windows. dasar pengambilan keputusan dengan melihat angka probabilitas apabila $\mathrm{p}>0,05$ maka data berdistribusi 
normal. selain uji prasyarat, dilakukan juga uji hipotesis menggunakan T-test. Dalam penelitian ini,, peneliti membandingkan kelompok kontrol dengan kelompok eksperimen sehingga teknik analisis data yang digunakan adalah t-test dengan bantuan SPSS. 19 for Windows pada taraf signifikan 5\%. Apabila $\mathrm{p}>0,05$ maka hipotesis diterima.

\section{HASIL DAN PEMBAHASAN}

Tabel 4.2 Distribusi Frekuensi Kelas VIIID

\begin{tabular}{cccc}
\hline NO & Rentang Nilai & F & Persentase (\%) \\
\hline 1 & $48-56$ & 5 & 15,625 \\
\hline 2 & $57-64$ & 3 & 9,375 \\
\hline 3 & $65-72$ & 10 & 31,25 \\
\hline 4 & $73-80$ & 7 & 12,875 \\
\hline 5 & $81-88$ & 4 & 12,5 \\
\hline 6 & $89-96$ & 3 & 9,375 \\
\hline & \multirow{2}{*}{ Jumlah skor $\left(\sum\right)$} & 32 & $100 \%$
\end{tabular}

Sumber data : olahan penulis, 2019

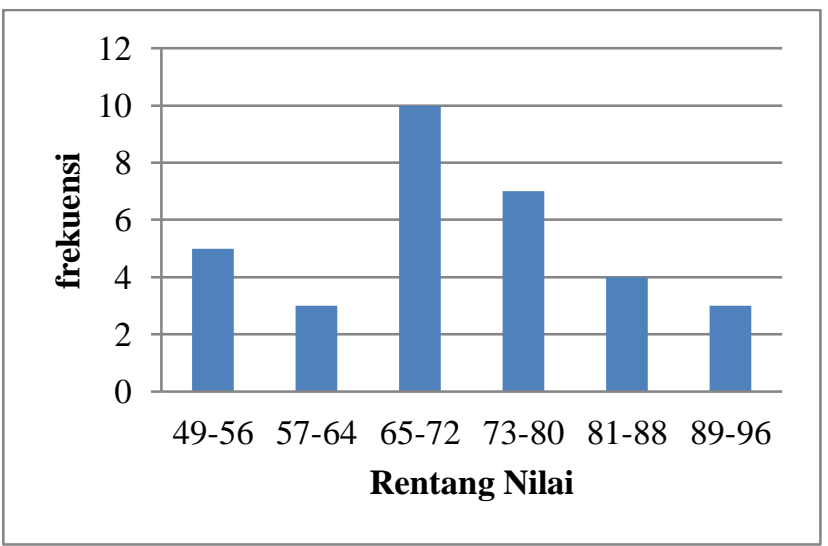

Gambar 4.1 Grafik/ Diagram Hasil Posstest Kelas Eksperimen

Tabel dan diagram posstest siswa kelas VIII ${ }^{\mathrm{D}}$ SMP Negeri 10 Kupang menunjukan bahwa siswa memperoleh nilai dari 49-56 terdapat 5 siswa dengan persentase $15,625 \%$. Dari nilai 57-64 terdapat 3 siswa dengan persentase $9,375 \%$. Dari nilai $65-72$ terdapat 10 siswa dengan persentase $31,25 \%$. Dari nilai $73-80$ terdapat 7 siswa dengan persentase 21,875 \%. Dari nilai 81-88 terdapat 4 siswa dengan presentase $12,5 \%$, Dari nilai 89 95 terdapat 3 siswa dengan presentase $9,375 \%$.
Tabel 4.4 Distribusi Frekuensi Kelas VIII ${ }^{\mathrm{A}}$

\begin{tabular}{|c|c|c|c|}
\hline No & Rentang Nilai & F & Persentase (\%) \\
\hline 1 & $08-16$ & 3 & 10 \\
\hline 2 & $17-25$ & 13 & 43,33 \\
\hline 3 & $26-34$ & 4 & 13,33 \\
\hline 4 & $35-43$ & 6 & 20 \\
\hline 5 & $44-52$ & 0 & 0 \\
\hline 6 & $53-61$ & 2 & 6,66 \\
\hline 7 & $62-70$ & 2 & 6,66 \\
\hline \multicolumn{2}{|c|}{ Jumlah skor $\left(\sum\right)$} & 30 & $100 \%$ \\
\hline
\end{tabular}

Sumber data : olahan penulis, 2019

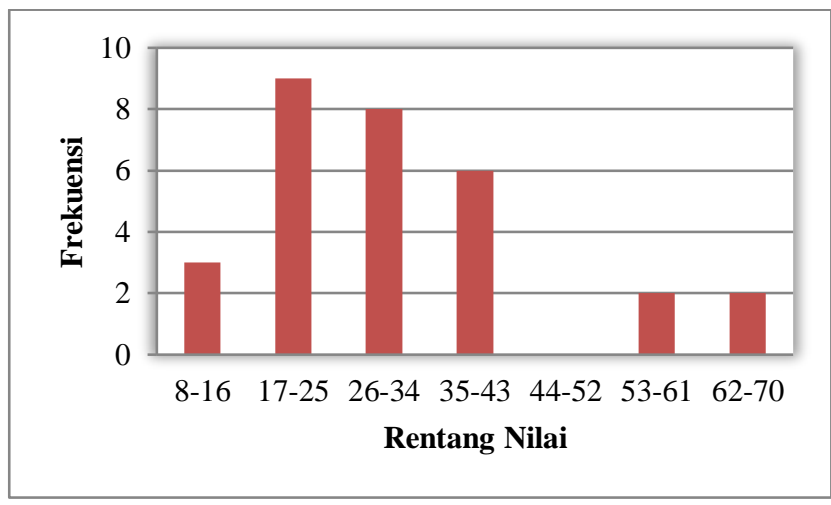

Gambar 4.2 Grafik/Diagram Hasil Posstest Kelas Kontrol

Tabel dan diagram posstest siswa kelas VII ${ }^{\mathrm{A}}$ SMP Negeri 10 Kupang menunjukan bahwa siswa memperoleh nilai dari 8-16 terdapat 3 siswa dengan persentase $10 \%$. Dari nilai 17-25 terdapat 13 siswa dengan persentase 43,33 \%. Dari nilai 26-34 terdapat 4 siswa dengan persentase $13,33 \%$. Dari nilai 35-43 terdapat 6 siswa dengan persentase $20 \%$. Tidak terdapat siswa yang memperoleh nilai 44-52. Dari nilai 53-61 terdapat 2 siswa dengan persentase $6,66 \%$. Dari nilai $62-70$ terdapat 2 siswa dengan persentase $6,66 \%$.

Perbandingan nilai rerata Posttest pada kelas eksperimen dan Kontrol dapat dilihat pada gambar 4.3 


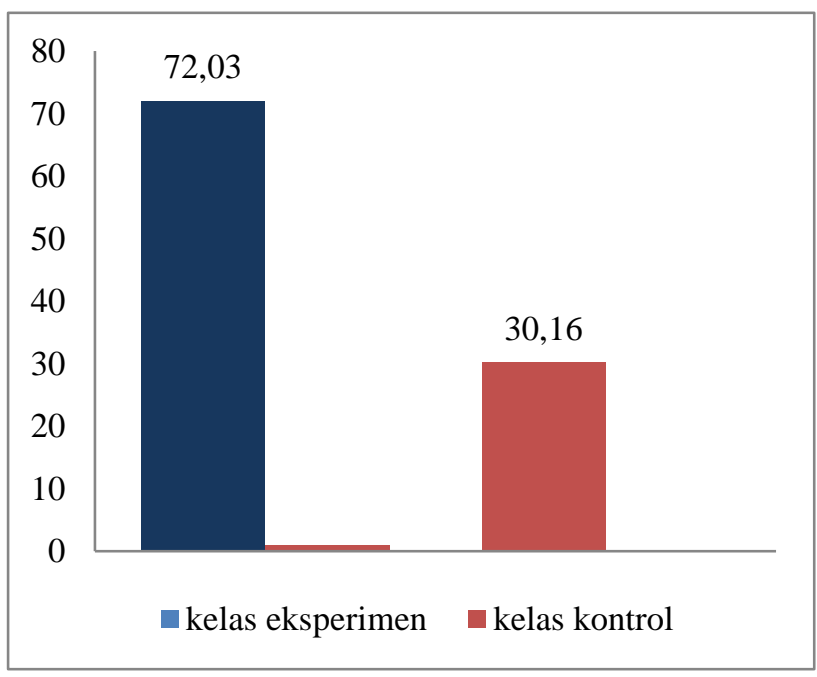

Gambar 4.3. Perbandingan Nilai Rerata Posttest

Dari gambar perbandingan nilai rata - rata Postest pada kelas eksperimen dan kelas kontrol terhadap kemampuan berpikir tingkat tinggi terdapat perbedaan yang sangatlah jauh. Selisih rata-rata dikedua kelas adalah 41,87. Selisih yang sangat jauh ini mengindikasikan bahwa terdapat perbedaan kemampuan berpikir tingkat tinggi (HOTS) yang dimiliki oleh siswa di kelas eksperimen dan di kelas kontrol.

Deskripsi nilai persentase aspek kognitif C4 - C6 hasil posstest yang mengikuti pembelajaran menggunakan model pembelajaran Problem Based Learning Berbantuan Media Couple Card dan pembelajaran yang menggunakan metode ceramah dapat dilihat pada Gambar 4.4.

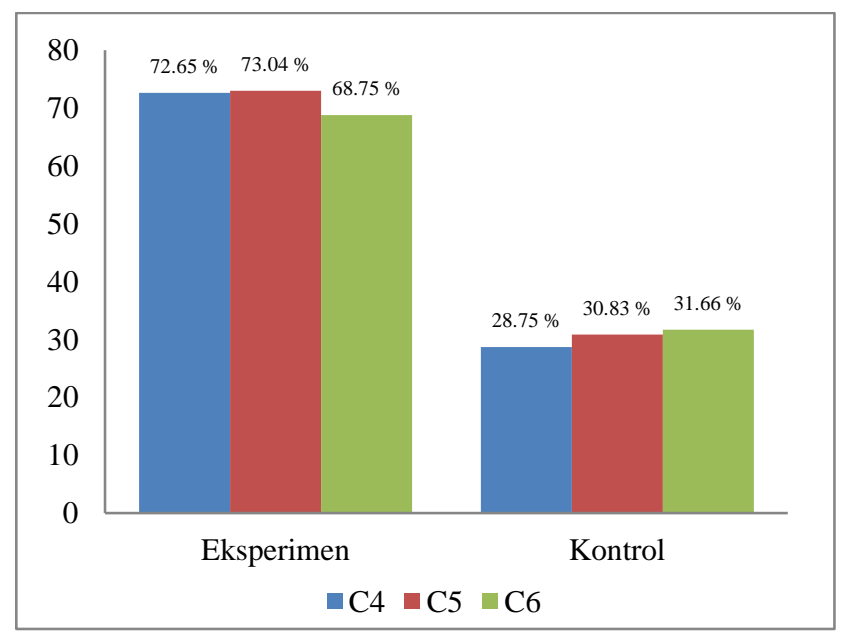

Gambar 4.4 Perbandingan Sebaran Skor Posstest

Berdasarkan grafik persentase aspek kognitif C4-C6 diatas hasil nilai posstest pada kelas eksperimen C5 memiliki persentase tertinggi dari C4 dan C6 sedangkan pada kelas kontrol, secara umum terlihat bahwa pada ranah C5 dan C6 memiliki persentase tertinggi dari ranah C4 (menganalisis). Namun secara khusus terlihat bahwa pada kelas eksperimen memilki persentase lebih tinggi dari kelas kontrol. Dimana pada kelas eksperimen, ranah kognitif C4 memilki persentase sebesar $72,65 \%$, ranah kognitif C5 memiliki persentase sebesar 73,04\%, dan ranah kognitif C6 memiliki persentase sebesar 68,75\%. Sedangkan, pada kelas kontrol ranah kognitif C4 memiliki persentase sebesar 28,75\%, ranah kognitif C5 memiliki persentase sebesar 30,83\%, dan ranah kognitif C6 memiliki persentase sebesar $31,66 \%$.

\section{UJI HOMOGENITAS}

Tabel 4.5 Uji homogenitas data penelitian

Nilai

\begin{tabular}{|c|c|c|c|}
\hline Levene Statistic & df1 & df2 & Sig. \\
\hline .267 & 1 & 60 & .608 \\
\hline
\end{tabular}

Berdasarkan Tabel 4.5 diketahui bahwa nilai signifikan adalah 0,608 atau lebih besar dari 0,05. Hal tersebut menunjukan bahwa data penelitian homogen.

\section{UJI NORMALITAS}

Tabel. 4.6. Uji normalitas Hasil Belajar Siswa

One-Sample Kolmogorov-Smirnov Test

\begin{tabular}{|cc|c|}
\hline & & hasil belajar hots \\
\hline \multicolumn{2}{|c|}{$\mathrm{N}$} & 62 \\
Normal & Mean & 51.77 \\
Parameters ${ }^{\mathrm{a}, \mathrm{b}}$ & Std. Deviation & 24.961 \\
Most Extreme & Absol ute & .152 \\
Differences & Positive & .152 \\
& Negative & -.129 \\
Kolmogorov-Smirnov Z & 1.200 \\
\multicolumn{2}{|c|}{ Asymp. Sig. (2-tailed) } & .112 \\
\hline
\end{tabular}

Berdasarkan data yang diperoleh dari hasil uji OneSample Kolmogorov-Smirnov Test dapat dikatakan bahwa data tersebut berdistribusi normal karena memiliki signifikan Asymp. Sig. (2-tailed) sebesar 0,112>0,05.

\section{UJI HIPOTESIS}

Hasil perhitungan uji normalitas dan homogenitas, menunjukan bahwa hasil belajar HOTS siswa berdistribusi normal, dan homogen. Sehingga uji hipotesis dapat digunakan dalam penelitian ini menggunakan uji statistik parametik yaitu uji t. Uji ini digunakan untuk mengambil keputusan apakah hipotesis diterima atau ditolak.

Pada Equal variances assumed diperoleh nilai $\mathrm{t}$ sebesar 12.241 dan taraf signifikan $\mathrm{p}=0,000$ atau kurang dari 0,05, maka dapat dikatakan $\mathrm{H}_{1}$ diterima dan $\mathrm{H}_{0}$ ditolak. Hal tersebut menunjukkan bahwa terdapat 
perbedaan hasil tes belajar HOTS siswa pada kelas eksperimen yang menggunakan model pembelajaran Problem Based Learning Berbantuan Media Couple Card terhadap Higher Order Thinking Skill Siswa dan kelas kontrol yang menggunakan metode ceramah. Fakta tersebut menunjukan bahwa model pembelajaran Problem Based Learning Berbantuan Media Couple Card terhadap Higher Order Thinking Skill Siswa memiliki potensi yang besar dalam mengembangkan tingkat berpikir siswa pada level kognitif Menganalisis (C4), Menilai/mengevaluasi (C5) dan Mencipta (C6).

Pembelajaran yang berlangsung pada kelas kontrol menggunakan model konvensional dengan menggunakan metode ceramah bervariasi meliputi ceramah, tanya jawab, diskusi - penugasan sehingga siswa hanya mendengarkan saja penjelasan dari peneliti. Namun dalam pelaksanaan pembelajaran keaktifan siswa kurang, terlihat hanya beberapa siswa yang mampu menjawab apabila diberi pertanyaan. Kurangnya penggunaan media yang bervariasi juga mempengaruhi kurangnya minat siswa dalam proses pembelajaran. Pembelajaran yang berlangsung dikelas eksperimen diberi perlakuan dengan menggunakan model problem based learning berbantuan media couple card telah dilaksanakan sesuai dengan 8 tahapan sintaks yang dicetuskan oleh Wena (2011). Pembelajaran berjalan dengan lancar karena siswa terlihat sangat antusias dan senang ketika melakukan proses pembelajaran di kelas, terlihat dari banyak siswa yang aktif terlibat dalam berbagai kegiatan pembelajaran untuk memecahkan masalah dan menggunakan ide atau gagasannya sendiri serta keinginan untuk mendapatkan jawaban dan memahami materi yang disampaikan. Dengan adanya kegiatan proses pembelajaran dengan pembelajaran Problem based learning berbantuan media Couple card sebagai media yang divariasikan dengan tujuan agar menarik siswa menjadi lebih aktif, memiliki minat, motivasi, kreatif, kritis serta kompetitif dalam memecahkan masalah yang di hadapinya serta memberi solusi rasional dalam mengembangkan kemampuan berpikir tingkat tinggi siswa itu sendiri.

$T$-tes dilakukan untuk menguji data hasil posstest. Dari Hasil pengolahan data uji t-test diperoleh nilai Sig (2 tailed) $=0,000$ dengan demikian $\mathrm{H}_{0}$ ditolak dan $\mathrm{H}_{1}$ diterima karena Sig (2-tailed) $<\alpha$ atau $(0,000<0,05)$. Hal ini menunjukan adanya pengaruh yang signifikan pada kemampuan berpikir tingkat tinggi pada hasil belajar antara kelas eksperimen yang menggunakan model pembelajaran Problem Based Learning berbantuan Media Couple Card dan kelas kontrol yang menggunakan metode ceramah. Dalam hal ini kemampuan berpikir tingkat tinggi yang di tinjau dari tes hasil belajar HOTS pada mata pelajaran IPA biologi siswa pada kelas eksperimen menunjukan pembelajaran dengan menggunakan model Problem Based Learning berbantuan media Couple Card memperoleh nilai siswa lebih tinggi dibandingkan dengan nilai siswa pada kelas kontrol yang menggunakan model pembelajaran konvensional. Hasil ini sejalan dengan hasil penelitian yang dilakukan oleh Royantoro, Febry, et al (2018) dalam penelitiannya menyatakan bahwa terdapat pengaruh signifikan terhadap HOTS peserta didik yang di ajar menggunakan model PBL dibandingkan dengan menggunakan model konvensional.

Dari hasil persentase analisis skor aspek kognitif C4, C5, dan C6 diperoleh data yaitu pada siswa kelas eksperimen memiliki skor yang lebih tinggi dari kelas kontrol baik pada soal C4, C5, maupun C6. Skor tertinggi diperoleh oleh kelas eksperimen pada soal C5 (menilai/mengevaluasi) yaitu dengan persentase 73,04\% dengan selisih 0,39 dengan soal menganalisis yang memperoleh persentase $72,65 \%$. berdasarkan hasil analisis peneliti, hal tersebut disebabkan karena siswa menjadi biasa untuk mengevaluasi suatu masalah setelah diterapkanya pembelajaran Problem Based Learning berbantuan media Couple Card. Faktor lain juga bisa di sebabkan karena siswa sudah mampu memahami maksud dari soal dan mampu menggunakan kemampuan berpikirnya sehingga siswa tidak kesulitan saat mengerjakan soal C5 dan C4. Pada soal C4 (menganalisis) mendapatkan persentase sebesar $72,65 \%$, memiliki persentase seperti itu karena siswa sudah mampu menganalisis dengan baik apa yang dimaksudkan pada soal seperti soal pada materi yang berkaitan dengan penyakit pada tulang, otot maupun pada kegiatan yang melibatkan pergerakan dalam kehidupan sehari-harinya. Sedangkan pada C6 (mencipta), dibandingkan C4 dan C5, C6 mendapatkan persentase $68,75 \%$ karena pada ranah ini peniliti mengajukan dengan 1 butir soal saja di karenakan pertimbangan pada soal C6 merupakan soal pada tingkat kognitif yang tinggi. Namun soal ini sudah mampu dijawab secara baik oleh siswa meskipun beberapa siswa masih salah dalam menjawab soal C6 (menilai).

Pada kelas kontrol persentase skor kognitif untuk soal C4 ( menganalisis) dengan persentase $28,75 \%$, soal C5 (mengevaluasi) dengan persentase skor $30,83 \%$ dan soal C6 (mencipta) dengan persentase skor $31,66 \%$. Hal ini di sebabkan karena pada kelas kontrol siswa tidak dilatih untuk merumuskan pemecahan masalah ataupun berkesempatan menggunakan kemampuan berpikir mereka. Siswa hanya menerima materi pembelajaran yang disampaikan guru. Faktor lain juga bisa di sebabkan karena siswa belum terbiasa dengan soal - soal menganalisis, mengevaluasi, dan mencipta. dan selama pembelajaran siswa lebih ditekankan untuk menghafal, sehingga pemahaman terhadap materi kurang mendalam.

Perbandingan nilai yang cukup signifikan pada kelas eksperimen dan kontrol baik itu ditunjukan dalam hasil hitungan nilai rata - rata maupun hasil analisis kognitif jenjang C4 - C6 menunjukan adanya perbedaan hasil tes belajar kemampuan berpikir tingkat tinggi (HOTS) setelah diterapkannya model dan media pembelajaran yang berbeda pada kelas eksperimen dan kontrol. Pada kelas eksperimen menggunakan media Couple Card sedangkan pada kelas kontrol menggunakan media Charta (gambar). Hasil tes belajar kemampuan berpikir tingkat tinggi (HOTS) menunjukan adanya Keunggulan pada pembelajaran menggunakan model pembelajaran berbasis masalah (PBL) terhadap kemampuan berpikir tingkat 
tinggi (HOTS). Keunggulan pembelajaran menggunakan model pembelajaran Problem Based Learning dengan media Couple Card terhadap HOTS siswa dibandingkan dengan pembelajaran yang tidak menggunakan model pembelajaran Problem Based Learning dengan media Couple card adalah dengan model ini dapat membuat kegiatan pembelajaran menjadi lebih menarik perhatian siswa, siswa menjadi aktif bekerja kelompok, siswa mampu memecahkan masalah yang dihadapinya dengan kemampuan berpikir secara ilmiah, meningkatkan daya ingat siswa dalam pelajaran lewat masalah nyata yang biasa dihadapinya dikehidupan sekitarnya. Siswa dapat mengembangkan kemampuan berpikirnya ketingkat lebih tinggi, berjiwa kompetitif, adanya motivasi belajar dengan divariasikannya dengan media pembelajaran kartu berpasangan yang merangsang siswa dalam proses pembelajaran sehingga siswa menjadi lebih santai dan menciptakan suasana yang menyenangkan dan membangun kerja sama dalam tim untuk menyelesaikan masalah secara bersama-sama.

Hasil penelitian ini menunjukan bahwa penerapan model Problem Based Learning berbantuan media Couple Card dalam pembelajaran terbukti lebih unggul meningkatkan kemampuan berpikir tingkat tinggi dari pada pembelajaran menggunakan metode ceramah bervariasi. Searah dengan hasil penelitian yang pernah dilakukan Gebriella (2016), bahwa media Couple Card dengan model pembelajaran Problem Based Learning (PBL) dapat meningkatkan hasil belajar siswa dan dapat meningkatkan kemampuan berpikir siswa. Dengan kata lain PBL berbantuan media Couple Card melatih siswa untuk mengembangkan dan meningkatkan kemampuan berpikir tingkat tinggi siswa.

\section{KESIMPULAN}

Berdasarkan hasil analisis dan pembahasan penelitian dapat disimpulkan bahwa ada pengaruh positif dan signifikan penerapan model Problem Based Learning berbantuan media Couple Card terhadap Higher Order Thinking Skill siswa pada IPA biologi. Hal ini dibuktikan dengan hasil uji hipotesis menggunakan rumus uji $\mathrm{t}$ dimana hasil analisis data pada perhitungan Independent Samples Test menunjukan nilai signifikan pada nilai Equal variances assumed mempunyai taraf signifikan Sig. (2tailed $)=0.000$ yang artinya $<0,05$. Hal ini berarti adanya perbedaan hasil belajar kemampuan HOTS siswa antara kelas eksperimen dan kelas kontrol sehingga $\mathrm{H}_{1}$ diterima dan $\mathrm{H}_{0}$ ditolak.

\section{REFERENSI DAN SITASI}

Abidin, Y. 2014. Desain Sistem Pembelajaran Dalam Konteks Kurikulum 2013. Bandung: PT Refika Aditama.

Djamarah \& Zain. 2006. Strategi belajar mengajar. Jakarta: Rineka Cipta.

Fathurrohman, M. 2017. Model - Model Pembelajaran Inovatif. Jogjakarta : AR-Ruzz Media
Gebriella, G. 2016. Pengaruh Model Problem Based Learning melalui Pendekatan Process Oriented Guide Inquiry dengan Media Kartu Berpasangan pada Materi Koloid Kelas XI SMA. Skripsi. Universitas Negeri Medan: Medan.

Heong, Y. M., et al. (2011). The Level Of Marzano Higher Order Thinking Skills among Technical Education Students. International Journal of Social Science and Humanity, 1 (2), 121-125.

Huda, M. 2018. Model - Model Pengajaran Dan Pembelajaran: Isu-Isu Metodis Dan Paradigmas. Jogjakarta: Pustaka Pelajar

Isjoni, H. 2013. Pembelajaran Kooperatif. Jogjakarta: Pustaka Pelajar.

Jumiati, Sari,M., Akmalia,D,.2011. Peningkatan Hasil Belajar Siswa Dengan Menggunakan Model Numbereds Heads Together (NHT) Pada Materi Gerak Tumbuhan Di Kelas VIII SMP Sei Putih Kampar. 2(2):161-185.

Mudlofir, A., dan Rusydiyah, F.E. 2016. Desain Pembelajaran Inovatif Dari Teori Ke Praktik. Jakarta: PT RajaGrafindo Persada

Mukrima, S., Syifa. 2014. 53 Metode Belajar Dan Pembelajaran Plus Aplikasinya. Bandung: Pendidikan Manajemen Bisnis A, Universitas Pendidikan Indonesia.

Noma, D, L., Prayitno, B, A., \& Suwarno. 2016. PBL Untuk Meningkatkan Kemampuan Berpikir Tingkat Tinggi Siswa Kelas X SMA. Jurnal Bioedukasi, 9 (2), 62-66

Nurhayati, N,. dan L, A. (2017). Analisis Kemampuan Berpikir Tingkat Tinggi Mahasiswa (Higher Order Thinking) dalam Menyelesaikan Soal Konsep Optika Melalui Model Problem Based Learning. Jurnal Penelitian Dan Pengembangan Pendidikan Fisika, 3(2), 119-125.

Rahmi, M., Fitriani., dan Kurniasih, D. 2018. Penggunaan Model Kooperatif Tipe Rotating Trio Exchange (RTE) Berbantuan Media Couple Card Pada Sub Materi Tata Nama Senyawa Hidrokarbon Terhadap Hasil Belajar Siswa Kelas XI IPA SMA Adisucipto Sungai Raya. Jurnal Ilmiah Ar-Razi, 6 (1): 79-87.

Riadi, A. 2016. Problem-Based Learning Meningkatkan Higher Order Thinking Skills Siswa Kelas VIII SMPN 1 Daha Utara dan SMPN 2 Daha Utara. Jurnal Pendidikan Matematika, 2 (3): 154-163.

Riyanto. 2010. Paradigma Pembelajaran Baru Pembelajaran sebagai Referensi bagi Pendidik dalam impelementasi Pembelajaran yang Efektif dan Berkualitas. Jakarta: Kencana Prenada Media Group.

Royantoro, F., et al. (2018). Pengaruh Model Problem Based Learning terhadap Higher Order Thinking Skills Peserta Didik. Berkala Ilmiah Pendidikan Fisika, 6(3), 371-382

Siregar, E., dan Nara, H., 2015. Teori Belajar Dan Pembelajaran Cet.4. Bogor: Ghalia Indonesia.

Sucipto. 2017. Pengembangan Keterampilan Berpikir Tingkat Tinggi Dengan Menggunakan Strategi Metakognitif Model Pembelajaran Problem Based Learning. Jurnal Pendidikan, 2 (1): 63-71 
Sugiyono. 2013. Metode Penelitian Pendidikan Pendekatan Kuantitatif, Kualitatif, dan R\&D. Bandung : Alfabeta

Sugiyono. 2016. Metode Penelitian Pendidikan Pendekatan Kuantitatif, Kualitatif, dan R\&D. Bandung : Alfabeta.

Susanto, A. 2013. Teori Belajar Dan Pembelajaran Disekolah Dasar. Jakarta: Prenadamedia Group.

Suwarsih, Mukti, Z., dan Prabowo, A. 2018. Meningkatkan Keterampilan Hots Siswa Melalui Permainan Kartu Soal dalam Pembelajaran PBL. Dalam http://www.Journalunnes.ac.id/sju/index.php/prisma/. Diakses tanggal 2 oktober 2018

Suyatno. 2009. Menjelajah Pembelajaran Inofatif. Sidoarjo: Masmedia Buana Pusaka
Suyono, dan Hariyanto,. 2015. Implementasi Belajar Dan Pembelajaran. Bandung: PT Remaja Rosdakarya

Trianto. 2007. Model Pembelajaran Terpadu Dalam Teori Dan Praktek. Jakarta: Prestasi Pustaka.

Trianto. 2010. Model Pembelajaran Terpadu Konsep, Strategi, dan Implementasinya dalam Kurikulum Tingkat Satuan Pendidikan (KTSP). Jakarta: Bumi Aksara.

Wena, M. 2013. Strategi Pembelajaran Inovatif kontemporer Suatu Tinjauan Operasional. Jakarta: Bumi Aksara.

Wicaktini, A. 2017. Pengaruh LKS Berbasis Problem Based Learning Terhadap Kemampuan Berpikir Tingkat Tinggi Siswa Pada Konsep Sistem Pencernaan. Skripsi. Universitas Islam Negeri Syarif Hidayahtullah: Jakarta. 